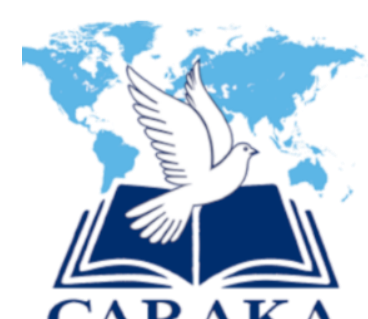

\title{
Ritus Pencurahan Darah Korban Binatang : Perjumpaan Injil Dengan Tradisi Manengeh Di Suku Dayak Bumate
}

\author{
David Eko Setiawan, Aniti Levina Taribaba, Dina Lorensa, Nopi \\ Sekolah Tinggi Teologi Tawangmangu \\ davidekosetiawan14217@gmail.com \\ ameltaribaba19@gmail.com \\ 10dinalorensa@gmail.com \\ anasnopi3@gmail.com
}

\begin{abstract}
This study aims to find the point of contac in preaching the gospel to the Dayak Bumate people through the Manengeh tradition. It turns out that in this tradition there are rites that are relevant to the heart of the gospel message, namely the sacrifice of animal blood. By discovering the meaning of shedding animal blood in the Manengeh tradition, the writer makes it a bridge in communicating the gospel to the Bumate Dayak tribe. The research method used in this research is qualitative descriptive using a library research approach and interviews. The results of this study indicate that the rite of shedding animal blood in the Manengeh tradition contains ideas that are relevant to the meaning of the sacrifice of Christ on the cross for the salvation of mankind, so through this rite the gospel message becomes relevant to the culture of the Dayak Bumate tribe.Keyword: culture; dayak; bumate; manengeh; blood; gospel
\end{abstract}

Keyword: Culture; Dayak; Bumate; Manengeh; Blood; Gospel

\begin{abstract}
Abstrak
Penelitian ini bertujuan untuk mencari point of contac dalam pemberitaan Injil kepada suku Dayak Bumate melalui tradisi Manengeh. Ternyata didalam tradisi tersebut terdapat ritus yang relevan dengan inti berita Injil yaitu korban pencurahan darah binatang. Dengan menemukan makna pencurahan darah binatang dalam tradisi Manengeh, penulis menjadikannya sebagai jembatan dalam mengkomunikasikan Injil kepada suku Dayak Bumate. Metode penelitian yang digunakan dalam penelitian ini adalah kualitatif deskriptif dengan menggunakan pendekatan library reseach dan wawancara. Hasil dari penelitian ini menunjukkan bahwa ritus pencurahan darah binatang dalam tradisi Manengeh mengandung gagasan yang relevan dengan makna korban Kristus di atas kayu salib bagi keselamatan umat manusia, maka melalui ritus tersebut berita Injil menjadi relevan dengan kebudayaan suku Dayak Bumate
\end{abstract}

Kata kunci: Budaya; Dayak; Bumate; Manengeh; Darah; Injil 


\section{PENDAHULUAN}

Setiap suku bangsa perlu mendengar dan menerima berita Injil. Maka dari itu Tuhan Yesus memerintahkan agar berita itu sampai kepada setiap suku bangsa. Perintah itu disebut dalam Injil Markus 13:10. Hal ini menunjukan bahwa berita keselamatan melalui Injil tidak hanya diperuntukkan bagi satu suku bangsa saja melainkan bagi semua suku bangsa. Di dalam Injil Matius 8:19-20 Tuhan Yesus memerintahkan kepada para murid untuk menjadikan segenap suku bangsa menjadi murid-Nya. Perintah ini sering disebut sebagai Amanat Agung Tuhan Yesus. Di dalam Amanat tersebut terdapat tiga kata kerja yang pendukung bagi perintah pemuridan itu, yaitu "pergilah", "baptislah" dan "ajarlah". ${ }^{1}$ Berdasarkan hal tersebut, tampak bahwa Tuhan Yesus ingin agar pemuridan ini berlangsung secara intens, sistematis dan berkelanjutan, maka dari itu berita Injil perlu diberitakan, didengar dan dipercayai oleh setiap manusia dari berbagai latar belakang kebudayaan ${ }^{2}$.

Inti berita Injil sesungguhnya adalah keselamatan di dalam Yesus melalui karya penebusan dosa di atas kayu salib. ${ }^{3}$ Karya ini telah dinubuatkan di dalam Perjanjian Lama dalam wujud pencurahan darah domba Paskah (Kel 8:22-23;12:1-28) dan digenapi dalam kematian Yesus Kristus. ${ }^{4}$ Peragaan tersebut dijelaskan oleh penulis surat Ibrani sebagai bayangan keselamatan yang akan datang (Ibrani 10:1). Pada pasal sebelunya penulis surat Ibrani menjelaskan bahwa tanpa pencurahan darah tidak ada pengampunan (Ibrani 9:22). ${ }^{5}$ Melalui pencurahan darah Tuhan Yesus di atas kayu salib sebagai korban yang sempurna, telah menyempurnakan untuk selama-lamanya, mereka yang dikuduskan (Ibrani 10:14).

Ritus korban pencurahan darah rupanya tidak asing bagi beberapa suku bangsa. Salah satunya pada suku Dayak Bumate di Kalimantan Barat. Suku ini merupakab sub suku dari Dayak Bidayuh-Somu yang kebanyakan menggunakan bahasa Bumate, sehingg mereka lebih sering disebut orang Bumate. ${ }^{6}$ Ritual pencurahan darah dalam budaya suku Dayak Bumate dimaknai sebagai suatu sarana yang untuk menjamin keselamatan bagi jiwa manusia. Ritual tersebut dimulai dengan mempersiapkan binatang yang akan dikorbankan untuk disembelih, lalu dipanjatkanlah doa kepada Tompo atau roh-roh leluhur agar semua prosesi pencurahan

\footnotetext{
${ }^{1}$ Ibelala Gea, "Beritakan Injil Kepada Segala Makhluk," BIA': Jurnal Teologi dan Pendidikan Kristen Kontekstual 1, no. 1 (2018): 57.

${ }^{2}$ Patrecia Hutagalung, "Pemuridan Sebagai Mandat Misi Menurut Matius 28:18-20," Pengarah: Jurnal Teologi Kristen 2, no. 1 (2020): 73.

${ }^{3}$ Harming Harming, "Metode Penginjilan Yesus Dalam Injil Yohanes 4:1-42," Evangelikal: Jurnal Teologi Injili dan Pembinaan Warga Jemaat 1, no. 2 (2017): 167-168.

4 Iman Nuel Zai and Thuan Ong, "Memahami Konsep Penebusan Dalam Hukum Taurat Dan Penggenapannya Dalam Diri Yesus Kristus,”Jurnal Teologi Pondok Daud 6, no. 1 (2020): 5.

5 Tison and Jermia Djadi, "Pengajaran Tentang Ibadah Berdasarkan Surat Ibrani 10:19-25 Dan Implimentasinya Dalam Kehidupan Orang Percaya Pada Masa Kini,” Jurna Jaffray 11, no. 1 (2013): 43.

${ }^{6}$ Kandida Maro Rayo, "Eksplorasi Kosakata Matematis Dalam Budaya Tak Kasat Mata Suku Dayak Bidayuh-Somu Di Desa Sebuduh Kecamatan Kembayan," Jurnal Pendidikan dan Pembelajaran Khatulistiwa 7 , no. 8 (2018): 8 .
} 
darah dapat berjalan dengan lancar. ${ }^{7}$ Setelah itu binatang disembelih dan darahnya ditumpahkan lalu dicurahkan pada parang atau benda-benda yang akan digunakan dalam prosesi adat Manengeh. ${ }^{8}$ Tujuan pencurahan darah korban binatang tersebut ialah sebagai jaminan keselamatan bagai jiwa manusia di suku Dayak Bumate Adapun jenis persembahan binatang yang akan disembelih ialah jenis binatang yang berkaki empat, berkaki dua dan yang tidak bercacat.

Telah ada beberapa kajian yang terkait dengan ritus pencurahan darah, semisal penelitian Salurante tentang ritus pemotongan hewan Kerbau di Toraja yang dikaitkan dengan korban tentang Tuhan Yesus. ${ }^{9}$ Penelitian sejenis lainnya adalah tentang nilai dan simbol religius perjamuan raya (Nado Mere) masyarakat Jawawawo yang dilakukan oleh Siu, dimana peneliti melakukan studi komparatif inkulturatif dengan nilai-nilai ekaristi pada upacara adat Nado Mere yang juga terkait dengan ritus persembahan darah korban binatang serta relevansinya dengan korban darah Yesus Kristus ${ }^{10}$. Selanjutnya penelitian Purwanto tentang makna korban dalam kitab Imamat. ${ }^{11}$ Dan juga penelitian tentang makna warna merah dalam tradisi orang Tiongha yang dikaitkan dengan darah Yesus. ${ }^{12}$ Namun demikian untuk penelitian terhadap ritus pencurahan darah dalam tradisi Manengeh pada suku Dayak Bumate belum banyak diteliti, khususnya berkaitan dengan usaha untuk menemukan point of contac bagi pemberitaan Injil di suku tersebut. Hal tersebut telah mendorong peneliti untuk mencari sumber-sumber data yang berkaitan dengan ritus tersebut dalam tradisi Manengeh. Penelitian ini bertujuan menggali konsep pencurahan darah dalam tradisi Manageh di suku Daya Bumate untuk menemukan titik temu yang relevan dengan konsep keselamatan di dalam Yesus Kristus sebagai inti dari berita Injil. Usaha ini penting karena pada dasarnya masyarakat suku Daya Bumate telah memiliki konsep yang relevan dengan korban Yesus Krsitus di atas kayu salib melalui budaya mereka. Hal ini akan lebih mudah untuk mengkontekstualisasikan Injil dalam budaya masyarakat yang tersapa. ${ }^{13}$

${ }^{7}$ Ibid., 4 .

${ }^{8}$ Berdasarkan wawancara dengan tetua adat suku Dayak Bumate yaitu bapak Mansyur pada tanggal 7 November 2020 pukul 12.30 WIB oleh Nopi maka didapatkan penjelasan bahwa tradisi Manengeh pada suku Dayak Bumate merupakan upacara adat yang diwariskan oleh leluhur mereka sebagai wujud ucapan syukur atas keberhasilan panen. Di dalam upacara ini dilakukan pemotongan binatang yang darahnya dicurahkan pada alatalat yang akan digunakan dalam upacara tersebut. Upacara ini juga merupakan wujud penghormatan kepada para leluhur mereka.

9 Tony Salurante, "Ritual Slaughtering of Livestock in 'Aluk Rambu Solo': How the Way of Torajan Appropriate the Doctrine of Jesus as Sacrifice," Diegesis Vol.5 No.2 (2020): 64-77.

${ }^{10}$ Hendrikus Primus Siu, "Nilai Dan Simbol Religius Perjamuan Raya ( Nado Mere ) Masyarakat Jawawawo : Studi Komparatif Inkulturatif Dengan Nilai-Nilai Ekaristi.," Jurnal Masalah Pastoral 3, no. 1 (2014): 15-36.

${ }^{11}$ Ani Teguh Purwanto, “Arti Korban Menurut Kitab Imamat,” Journal Kerusso 2, no. 2 (2017): 8-14.

12 Deky Nofa Aliyanto and Sinta Kumala Sari, "Makna Warna Merah Dalam Tradisi Etnis Tionghoa Sebagai Jembatan Komunikasi Untuk Memperkenalkan Makna Darah Yesus," Jurnal Gamaliel : Teologi Praktika 1, no. 2 (2019): 203.

${ }^{13}$ David Eko Setiawan, "Menjembatani Injil Dan Budaya Dalam Misi Melalui Metode Kontektualisasi," 3 | Copyright@ 2021, CARAKA, ISSN 2722-1407 (Cetak), 2722-1393 (Online) 


\section{METODE PENELITIAN}

Metode yang digunakan dalam penelitian ini adalah kualitatif deskriptif. Melalui metode ini peneliti berusaha untuk menjelaskan hal ihwal masalah atau objek tertentu secara rinci. ${ }^{14}$ Adapun untuk mengumpulkan data-data yang ada, peneliti menggunakan pendekatan kepustakaan ${ }^{15}$ dan metode survei melalui wawancara kepada para peserta budaya Manengeh. ${ }^{16}$ Peserta budaya yang dimaksud di dalam penelitian ini adalah anggota masyarakat suku Dayak Bumate yang terlibat di dalam upacara adat Manengeh. Ada pun mereka adalah tetua adat, tokoh spiritual dan anggota masyarakat biasa yang menjadi pelaku budaya tersebut. Diharapkan melalui mereka akan didapatkan data-data otentik berkaitan dengan tradisi Manengeh tersebut. Selanjutnya data-data yang dikumpulkan dengan menggunakan pendekatan library reseach akan dianalisa dengan menggunakan conten analysis. Analisis ini menitikberatkan pada penafsiran atas bahan-bahan literatur untuk mendapatkan jawaban atas problem reseach. ${ }^{17}$ Sedangkan untuk data-data hasil wawancara akan dianalisis dengan menggunakan analisis isi dan deskriptif.

Dalam penelitian ini juga melibatkan teologi kontekstualisasi, sedangkan Model teologi kontekstual yang dipakai adalah model sintesis. Model sintesis berupaya mengembangkan segala sesuatu secara dialektis dan kreatif sehingga dapat diterima dari berbagai sudut pandang. ${ }^{18}$ Sedangkan langkah awal dalam model sintesis ini adalah memahami dan mendengarkan tradisi Manengeh, dan selanjutnya menganalisis segala sesuatu yang berkaitan baik praktis Kristen, non agama dan kepercayaan lain. ${ }^{19}$ Untuk penerapan dari model sintesis ini harus tetap memperhatikan konteks budaya dimana Injil dan budaya ini berjumpa.

Peneliti menggunakan langkah-langkah model sintesis menurut Banawiratna sebagai berikut: ${ }^{20}$ Pertama, momen pengalaman. Pada tahapan ini peneliti berusaha mengumpulkan data pengalaman melalui wawancara dan juga mengamati tradisi-tradisi yang masih hidup dan menjadi pegangan para peserta budaya. Selanjutnya data pengalaman itu dikumpulkan, dicatatat dan dirumuskan serta dapat dibantu dengan analisis menggunakan ilmu-ilmu yang lain. Tahapan terakhir dari momen pengalaman adalah membuat fokus refleksi dari seamua data pengalaman yang telah dikumpulkan dan dianalisa. Kedua, momen keprihatinan iman.

Fidei: Jurnal Teologi Sistematika dan Praktika 3, no. 2 (2020): 160-180.

${ }^{14}$ Bagong Suyanto, Metode Penelitian Sosial: Berbagai Alternatif Pendekatan (Jakarta, 2015), 14.

${ }^{15}$ Kartini Kartono, Pengantar Metodologi Research Sosial (Bandung: Alumni Bandung, 1980), 78.

${ }^{16}$ M. A. Morrisan, Metode Penelitian Survei (Jakarta, 2012), 26.

${ }^{17}$ Kartono, Pengantar Metodologi Research Sosial, 78.

${ }^{18}$ Ayub Warjianto and Fibry Jati Nugroho, "Teologi Penghormatam : Dialog Kekristenan Dengan Ritus Kembang Kuningan,” Visio Dei: Jurnal Teologi Kristen 2, no. 1 (2020): 150.

${ }^{19}$ Ibid.

${ }^{20}$ J.B. Banawiratma, "Teologi Fungsional-Teologi Kontekstual," in Konteks Berteologi Di Indonesia, ed. Eka Darmaputera (Jakarta: Gunung Mulia, 2004), 54-61. 
Pada momen ini peneliti membuat dua langkah penting yaitu (1) menemukan tindakan moral dan religius dan (2) merumuskan keprihatinan iman. Ketiga, momen sitesis teologi. Pada momen inilah terjadi dialog antara tradisi tertulis dari iman Kristen, tradisi praksis Kristiani, dan tradisi budaya lokal. Disinilah sintesis teologi dilakukan dengan menyandingkan datadata yang telah dianalisis. Keempat, momen rencana pastoral. Di dalam momen ini dilakukan orientasi pastoral untuk menyikapi ritus budaya setempat. Pada momen orientasi pastoral, sintesis teologis yang telah dirumuskan belum secara eksplisit mempunyai orientasi pastoral. Teologi kontekstual mampunyai fungsi dalam komunikasi iman. Teologi kontekstual memberikan sumbangan bagi pembinaan penghayatan iman umat, baik yang menyangkut pengungkapan atau pelaksanaan iman. Selanjutnya menyusun program pastoral. Akhirnya orientasi pastoral itu harus dirumuskan secara konkret dalam program pastoral. Melalui program yang konkret, teologi kontekstual akan memberikan pengamalaman baru dan dapat mulai dengan proses refleksi yang baru.

\section{HASIL DAN PEMBAHASAN}

\section{Mengenal Suku Dayak Bumate}

Suku dayak Bisomu juga dapat disebut sebagai suku dayak Bumate. ${ }^{21}$ Wiwin menjelaskan hal tersebut sebagai berikut: "hal ini dilakukan untuk membedakan dialek yang sedikit berbeda dengan dialek sub suku Bidayuh lainnya". ${ }^{22}$ Bumate itu merupakan bahasa dari sub suku ini, dan Bumate berasal dari dua kata yaitu $B u$ yang artinya memiliki dan mate yang artinya nanti, sehingga Bumate dapat diartikan bernanti. ${ }^{23}$ Penamaan terhadap orang Bumate sebenarnya dilakukan oleh sub suku lain yang hidup berdampingan dengan mereka, yang ingin memberikan ciri khusus berdasarkan dialeknya. ${ }^{24}$

Latar belakang suku dayak Bumate tidaklah berbeda jauh dengan suku dayak Bisomu. Secara umum, mata pencaharian orang Bumate mirip dengan sebagian besar suku dayak lainnya, yaitu bertani, berkebun, dan menjadi pegawai pemerintah dan swasta. ${ }^{25}$

Suku dayak Bumate memiliki sebuah tradisi yang unik yaitu Manengeh. Tradisi ini merupakan upacara adat yang dilakukan untuk menunjukkan rasa ucapan syukur masyarakat adat terhadap hasil panen yang mereka peroleh. Melalui Manengeh ini, orang Bumate mengekspresiakan rasa syukur tersebut dengan menyelenggarakan prosesi adat yang dipimpin

21 Tea Tasia Wiwin, "Matematika Dalam Budaya Memperingati Anak Bulan Di Masayarakat Suku Dayak Dusun Terusan Kalimantan Barat," in Matematika Dalam Budaya: Kumpulan Kajian Etnomatematika, ed. M. Andy Rudhito, FX. Catur Supatmono, and Gabriela Purnama Ningsi (Yogyakarta: Garudhawaca, 2019 ), 80.

${ }^{22}$ Ibid.

${ }^{23}$ Kalis. Arti Kata Bumate. Wawancara oleh David. 11. November 2020. Pukul 14.30 WIB.

${ }^{24}$ Ibid

${ }^{25}$ Wiwin, "Matematika Dalam Budaya Memperingati Anak Bulan Di Masayarakat Suku Dayak Dusun Terusan Kalimantan Barat," 81. 
oleh kepala suku mereka. Di dalam prosesi tersebut terdapat ritus pencurahan darah binatang yang memiliki makna penting bagi masyarakat adat suku Bumate. Ritus ini harus dilaksanakan agar menjamin keselamatan jiwa tiap-tiap anggota suku tersebut.

\section{Korban Pencurahan Darah Binatang di dalam Tradisi Manengeh}

Suku dayak Bumate memilki tradisi yang menarik yaitu Manengeh. Berdasarkan wawancara terhadap salah satu tetua adat suku Bumate, tradisi tersebut merupakan bentuk kebudayaan orang Bumate dalam mensyukuri hasil panen mereka. ${ }^{26}$ Bagi orang Bumate keberhasilan dalam panen tidak lepas dari pertolongan roh-roh yang mendiami tempat-tempat tertentu, seperti mata air, gunung, sungai, pohon, batu, dan lain sebagainya. ${ }^{27}$ Untuk menghormati peran mereka serta "menenangkan" roh-roh tersebut maka dilaksakanlah beberapa prosesi dalam tradisi Manengeh ini.

Inti dari tradisi Manengeh, tampak dalam prosesi adat pencurahan darah binatang, dimana dalam prosesi ini terdapat korban binatang yang disembelih dan darahnya dicurahkan ke atas peralatan-peralatan yang akan digunakan dalam ritual tersebut. ${ }^{28}$ Tujuan dari pencurahan darah binatang sebagai penghormatan atas perjanjian antara manusia dengan Tompo (baca: Tuhan) yang suci dan yang telah memberikan jaminan keselamatan bagi para peserta budaya. ${ }^{29}$ Bagi orang Bumate, darah mengandung nilai yang sakral, luhur dan dianggap sebagai pengganti nyawa manusia. ${ }^{30}$ Maka, menurut tetua adat setempat, ritual pencurahan darah dalam tradisi Manengeh harus ada, jika tidak akan membahayakan keselamatan orang Bumate. ${ }^{31}$

Bagi masyarakat suku Bumate, darah juga memiliki manfaat untuk menetralisir dari segala anasir-anasir jahat yang dapat mengangu mereka. ${ }^{32}$ Cara menggunakannya yaitu pada saat ritual pencurahan darah binatang, darah tersebut akan ditampung dalam wadah lalu dipercikkan oleh tetua adat kepada peralatan-peralatan yang dibawa oleh peserta acara tersebut, salah satunya adalah parang. Diyakini, darah itu akan menetralisir kekuatan-keuatan jahat yang berniat menggagalkan panen atau membahayakan kehiduan msayarakat dayak Bumate.

\footnotetext{
${ }^{26}$ Mansyur. Tradisi Manengeh. Wawancara oleh Nopi. 7. November 2020. Pukul 12.30 WIB.

${ }^{27}$ Mincok. Kebehasilan Panen bagi Orang Bumate. Wawancara oleh Nopi. 7. November 2020. Pukul $13.00 \mathrm{WIB}$

${ }^{28}$ Mansyur. Tradisi Manengeh. Wawancara oleh Nopi. 7. November 2020. Pukul 12.30 WIB

${ }^{29}$ Mansyur. Darah dalam Tradisi Manengeh. Wawancara oleh Nopi. 7. November 2020. Pukul 12.30

WIB

${ }^{30}$ Luncet. Makna Darah bagi Orang Bumate. Wawancara oleh Dina. 8 November 2020. Pukul 10.00

WIB

${ }^{31}$ Mansyur. Darah dalam Tradisi Manengeh. Wawancara oleh Nopi. 7. November 2020. Pukul 12.30

WIB

${ }^{32}$ Rona. Makna Darah bagi Orang Bumate. Wawancara oleh Nopi. 8. Aniti 2020. Pukul 12.30 WIB
} 


\section{Prosesi Tradisi Manengeh dan Maknanya}

Menurut tetua adat suku dayak Bumate, terdapat beberapa tahapan (baca: prosesi) dalam melaksakanan tradisi Manengeh, yaitu: ${ }^{33}$ Pertama, penentuan waktu dan tempat bagi pelaksanaan upacara adat Manengeh. Untuk menentukannya, lebih dahulu diadakan pertemuan antara kepala suku dengan seluruh masyarakat Bumate. Di dalam pertemuan tersebut akan diputuskan hari, tanggal, waktu, tempat beserta seluruh peralatan yang akan digunakan dalam pelaksanaan tradisi Manegeh tersebut. Makna yang terkandung dalam penentuan waktu, tempat dan alat-alat yang akan digunakan adalah penghormatan akan siklus alam dan isinya. Suku dayak Bumate sangat menghormati alam dan siklus yang terjadi di dalamnya. Dengan menentukan waktu dan tempat secara tepat diyakini adanya keharmonisan antara manusia dengan alam. Selain itu, masyarakat Bumate juga menghargai kerukunan dan keharmonisan antar anggotanya, sehingga setiap keputusan yang berdampak pada kesejahteraan masyarakat adat, harus diputuskan secara bersama. Kedua, mengadakan ritual Ensanggi Rangka. ${ }^{34}$ Dalam ritual ini dilakukan doa oleh tokoh spiritual suku Bumate sehari sebelum upacara adat dilangsungkan. Doa yang dilantunkan kepada roh-roh nenek moyang tersebut bertujuan agar upacara adat tradisi Manageh yang akan dilakukan dapat berjalan dengan lancar dan aman, tanpa gangguan. Para peserta upacara adat akan datang dengan membawa korban lalu mendengarkan doa yang dilantunan berikut: "Rinak bu pulua Timpo Linua, Rina Bu Poyo Tompo Roto" Makna dari ritual Esanggi Rangka adalah penghormatan orang Bumate terhadap para leluhurnya. Mereka percaya bahwa roh-roh leluhur itu berperan juga dalam keberhasilan setiap usaha. Ketiga, pelaksanaan upacara adat tradisi Manegeh. Tradisi Manengeh pada dasarnya merupakan bentuk ucapan syukur kepada Tompo atau para leluhur yang telah memberikan keberhasilan dalam masa bercocok tanam hingga panen. Dalam perayaan upacara adat tersebut, seluruh masyarakat adat dayak Bumate akan hadir di satu tempat yang telah disepakati hari dan waktunya. Biasanya kampung yang ditunjuk akan membuka diri bagi warga Bumate dari kampung lain serta menjamu mereka selama dua hari berturut-turut. Sebagai tuan rumah yang baik, mereka akan bertanggung jawab kepada para tamu yang hadir. Di dalam upacara adat tradisi Manengeh ini akan dilakukan ritul pencurahan darah binatang yang akan dipercikkan pada alat-alat yang dikumpulkan dalam upacara tersebut. Makna dari pencurahan darah ini adalah untuk mensakralkan acara tersebut, serta permohonan perlindungan bagi masyarakat dayak Bumate. Selain itu juga ada beras kuning

\footnotetext{
${ }^{33}$ Mansyur. Darah dalam Tradisi Manengeh. Wawancara oleh Nopi. 7 November 2020. Pukul 12.30 WIB

${ }^{34}$ Berdasarkan wawancara dengan tetua adat suku Dayak Bumate yaitu bapak Mansyur pada tanggal 7 November 2020 pukul 12.30 WIB oleh Nopi, Ensanggi Rangka merupakan salah satu ritus yang da di dalam tradisi Manengeh dalam bentuk doa kepada roh-roh nenek moyang suku Dayak Bumate oleh tokoh spiritual di suku tersebut. Doa ini dilakukan untuk mengawali seluruh rangkaian upaca adat Manengeh agar semua prosesi berjalan dengan aman dan lancar.
}

7 | Copyright $@$ 2021, CARAKA, ISSN 2722-1407 (Cetak), 2722-1393 (Online) 
yang ditabur sebagai sarana untuk mengundang roh-roh leluhur. Makna dari ritus ini adalah penghormatan bagi para leluhur yang telah memberikan keberhasilan dalam panen. Disamping itu juga dilantunkan musik tradisional dan disajikan minuman tuak sebagai penghormatan bagi para tamu yang hadir. Keempat, upacara penutup yang ditandai pembagian daging hewan yang telah dikorbankan kepada setiap peserta upacara adat tradisi Manengeh. Makna dari prosesi ini menunjukkan rasa syukur atas keselamatan dalam upacara adat tersebut.

\section{Korban Pencurahan Darah Binatang di dalam Alkitab.}

Perjanjian Lama (PL) menyajikan banyak informasi tentang korban pencurahan darah binatang. Semenjak dalam Kejadian 3:21, pencurahan darah korban binatang telah diperkenalkan pasca kejatuhan manusia dalam dosa. ${ }^{35}$ Menurut Park, bintang yang dibunuh dan dicurahkan darahnya tersebut menjadi korban penghapusan dosa. ${ }^{36}$ Lalu di dalam kitab Keluaran 12, disinggung kembali tentang praktek pencurahan darah yang dikaitkan dengan terlepasnya bangsa Israel dari tulah kesepuluh di Mesir, disitu tampak bahwa tanda darah domba atau kambing yang dibubuhkan pada kedua tiang pintu dan pada ambang atas telah melepaskan anak sulung Israel dari kematian. ${ }^{37}$

Selanjutnya di dalam kitab Imamat juga disajikan tentang korban pencurahan darah binatang. Purwanto menjelaskan bahwa korban-korban yang diberikan Israel kepada Allah dalam kitab Imamat dimaknai sebagai substitusi nyawa mereka sendiri. ${ }^{38}$ Lalu Purwanto menegaskan bahwa gagasan tersebut tampak jelas dalam peristiwa pencurahan darah dari korban-korban tersebut, dan darah itu bukan mengandung unsur yang gaib, tetapi diterima Allah sebagai pengganti nyawa atau sebagai tebusan dari orang yang beribadah itu. ${ }^{39}$

Berdasarkan penjelasan di atas, tampak jelas bahwa korban binatang yang dicurahkan darahnya menjadi begitu penting dalam Perjanjian Lama, sebab di dalamnya mengandung makna substitusi dan penyelamatan bagi mereka yang mengorbankan.

Sedangkan di dalam Perjanjian Baru (PB), praktek pencurahan darah korban binatang dalam PL dimaknai sebagai bayangan dari keselamatan yang akan datang. Korban pencurahan darah binatang dalam PL merupakan bayangan dari karya penyelamatan Kristus yang sempurna. ${ }^{40}$ Hal tersebut dinyatakan oleh penulis Ibrani dalam suratnya. Di dalam surat Ibrani 10, penulis sedang menunjukkan kepada para pembacanya bahwa korban Tuhan Yesus

${ }^{35}$ Deky Nofa Aliyanto and Sinta Kumala Sari, "Makna Warna Merah Dalam Tradisi Etnis Tionghoa Sebagai Jembatan Komunikasi Untuk Memperkenalkan Makna Darah Yesus” 1, no. 2 (2019): 101.

${ }^{36}$ Yune Sun Park, Tafsiran Kitab Kejadian (Batu: Dept. Literatur YPPII, 2002), 35.

37 Aliyanto and Sari, "Makna Warna Merah Dalam Tradisi Etnis Tionghoa Sebagai Jembatan Komunikasi Untuk Memperkenalkan Makna Darah Yesus," 101.

${ }^{38}$ Purwanto, "Arti Korban Menurut Kitab Imamat," 11.

${ }^{39}$ Ibid.

${ }^{40}$ Ibid., 13. 
merupakan korban yang sempurna, kontras dengan korban-korban yang dipersembahkan di dalam PL. ${ }^{41}$ Sebab melalui pengorbanan-Nya, Kristus telah menyucikan sekali untuk selamalamanya mereka yang dikuduskan-Nya. ${ }^{42}$

Signifikansi pencurahan darah Yesus di atas kayu salib adalah sebagai berikut: ${ }^{43}$ Pertama, memberikan pengampunan bagi mereka yang bertobat dan percaya (Mat.26:8). Kedua, menebus semua orang percaya dari kejahatan dan kuasa Iblis (Kis. 20:28; Ef. 1:7; 1 Pet.1:18-19; Why. 5:9). Ketiga, membenarkan semua orang yang percaya kepada-Nya (Roma 3:24-25). Keempat, menyucikan hati nurani semua orang percaya sehingga dapat melayani Allah dengan penuh keyakinan (Ibr. 9:14; 10:22; 13:18). Kelima, membuka jalan bagi semua orang percaya untuk dapat langsung menghampiri Allah (Ibr. 7:25; 10:19; Ef. 2:13,18). Keenam, jaminan untuk semua janji dari perjanjian baru (Ibrani 10:29; 13:20; 1 Kor 11:25). Ketujuh, menghapus kesalahan yuridis orang percaya (Ibr. 10: 22; 1 Yoh. 1:7).

\section{Persamaan dan Perbedaan Ritus Pencurahan Darah Korban Binatang dalam Tradisi Manengeh dengan Alkitab}

Jika diamati secara teliti maka akan didapatkan persamaan dan perbedaan makna ritus pencurahan darah korban binatang dalam tradisi Manengeh dengan yang ada di dalam Alkitab. Persamaannya adalah sebagai berikut: Pertama, keduanya berkaitan dengan jaminan keselamatan manusia. Di dalam tradisi Manengeh, darah yang dicurahkan dari korban binatang bermanfaat bagi perlindungan dan keselamatan bagi peserta budaya yaitu masyarakat adat Bumate dari segala anasir-anasir jahat yang dapat merugikan kehidupan mereka. Gagasan tentang jaminan keselamatan tersebut juga ada di dalam upacara pencurahan darah korban binatang di dalam Alkitab. Bangsa Israel yang membawa korban binatang yang disembelih mendapatkan jaminan keselamatan dari murka Allah atas dosa-dosanya sehingga melaluinya terjadi pendamaian antara Allah dengan manusia. ${ }^{44}$ Kedua, ritus pencurahan dan pemercikan darah korban binatang diperantarai oleh seorang tokoh spiritual. Di dalam budaya suku dayak Bumate, korban binatang tersebut diserahkan kepada tokoh spiritual kampung yang diyakini dapat menjadi medium dengan Tompo (roh-roh leluhur). Melaluinya, korban binatang diterima dan darahnya dipercikkan pada peralatan-peralatan yang akan digunakan dalam upacara adat Manengeh. Demikian juga di dalam Alkitab, korban binatang diserahkan kepada imam, lalu sang pemberi korban harus meletakkan tangannya di atas binatang tersebut kemudian menyembelihnya (Imamat 4). Selanjutnya darah korban binatang itu dipercikkan di depan

41 Tison and Djadi, "Pengajaran Tentang Ibadah Berdasarkan Surat Ibrani 10:19-25 Dan Implimentasinya Dalam Kehidupan Orang Percaya Pada Masa Kini," 41.

${ }^{42}$ Aliyanto and Sari, "Makna Warna Merah Dalam Tradisi Etnis Tionghoa Sebagai Jembatan

Komunikasi Untuk Memperkenalkan Makna Darah Yesus,” 101.

${ }^{43}$ Ibid., 98-99.

${ }^{44}$ Purwanto, "Arti Korban Menurut Kitab Imamat," 8. 
tabir Kemah Suci dan dioleskan pada tanduk-tanduk mezbah (Imamat 4). ${ }^{45}$ Ketiga, korban binatang yang akan disembelih telah dipilih dan dipersiapkan lebih dahulu. Pada tradisi Manengeh, binatang yang akan disembelih telah dipersiapkan lebih dahulu sebelum upacara adat tersebut berlangsung. Demikian pula dalam Alkitab, binatang yang akan dipersembahkan sebagai korban harus dipersiapkan dan tidak bercacat, tidak bercela (Imamat. 22:20; 22:21). Keempat, korban pencurahan darah dalam tradisi Manengeh dan dalam Alkitab memiliki inti yang sama yaitu sebagai sarana pendamaian dan ucapan syukur. Menurut Imamat 7:37, ada lima jenis korban yang diperintahkan Tuhan di Gunung Sinai, namun meskipun tujuannya berbeda-beda namun intinya tetap sama yaitu sebagai pendamian dan ucapan syukur. ${ }^{46}$ Kelima, dalam tradisi Manengeh dan dalam Alkitab, korban pencurahan darah dimaknai sebagai substitusi nyawa para pemberi korban.

\section{Tabel 1. Persamaan Ritus Pencurahan Darah dalam Tradisi Manengeh dan dalam Alkitab}

\begin{tabular}{|c|c|}
\hline No & Tradisi Manengeh dan Alkitab \\
\hline 1 & Sama-sama berkaitan dengan jaminan keselamatan jiwa manusia \\
\hline 2 & Adanya Tokoh Spiritual yang menjadi perantara dalam ritus tersebut \\
\hline 3 & $\begin{array}{l}\text { Bintang yang akan dijadikan korban harus dipersiapkan dan diseleksi } \\
\text { lebih dahulu }\end{array}$ \\
\hline 4 & $\begin{array}{l}\text { Makna ritus memiliki kemiripan yaitu untuk pendamian dan ucapan } \\
\text { syukur }\end{array}$ \\
\hline
\end{tabular}

Sedangkan perbedaan antara korban pencurahan darah binatang dalam tradisi Manengeh dengan yang ada di Alkitab adalah sebegai berikut: Pertama, binatang yang dipersembahkan dalam acara adat Manengeh berbeda dengan yang ada di Alkitab. Dalam tradisi Manengeh binatang yang menjadi korban adalah babi dan ayam, sedangkan di dalam Alkitab adalah lembu, domba, kambing atau merpati (Imamat 1:1-7:38). Kedua, dalam tradisi Manengeh, daging korban akan dibagikan kepada peserta setelah ritual selesai, sedangkan di dalam Alkitab daging korban itu diatur sedemikian rupa sehingga ada yang menjadi bagian dari Imam Besar dan imam-imam yang lain namun juga ada yang menjadi bagian dari seseorang yang membawa korban tersebut (Imamat 7:1-38). Ketiga, makna ritus pencurahan darah korban binatang di dalam tradisi Manengeh hanya dipahami sebagai subsitusi nyawa

${ }^{45}$ H.H. Rowley, Ibadah Israel Kuno (Jakarta: BPK Gunung Mulia, 1981), 73.

${ }^{46}$ Purwanto, "Arti Korban Menurut Kitab Imamat," 10. 
sang pemberi korban, penghilang anasir-anasir jahat dan penguat ikatan perjanjian dengan Tompo (roh-roh leluhur), sedangkan didalam Alkitab ritus pencurahan darah ini memiliki makna yang lebih tinggi yaitu merujuk kepada karya keselamatan di dalam Yesus Kristus, dimana dengan darah-Nya , manusia berdosa ditebus dan diselamatkan.

Tabel 2. Perbedaan Ritus Pencurahan Darah dalam Tradisi Manengeh dan dalam Alkitab

\begin{tabular}{|l|l|l|}
\hline No & \multicolumn{1}{|c|}{ Tradisi Manengeh } & \multicolumn{1}{c|}{ Alkitab } \\
\hline 1 & $\begin{array}{l}\text { Binatang yang dijadikan korban } \\
\text { adalah Babi dan ayam }\end{array}$ & $\begin{array}{l}\text { Binatang yang dijadikan korban } \\
\text { adalah lembu, kambing, domba dan } \\
\text { burung merpati }\end{array}$ \\
\hline 2 & $\begin{array}{l}\text { Setelah darah korban dicurahkan } \\
\text { maka daging korban langsung } \\
\text { dibagikan ke semua peserta } \\
\text { upacara adat Tradisi Manengeh }\end{array}$ & $\begin{array}{l}\text { Setelah darah korban maka daging } \\
\text { korban diatur pembagiannya oleh } \\
\text { Imam; ada yang menjadi bagian } \\
\text { Imam Besar dan para imam juga } \\
\text { ada yang dibawa pulang (Imamat } \\
7: 1-38)\end{array}$ \\
\hline 3 & $\begin{array}{l}\text { Pencurahan darah korban binatang } \\
\text { hanya dimaknai subtitusi nyawa } \\
\text { sang pemberikorban, penetralisir } \\
\text { anasir-anasir jahat, penguat } \\
\text { perjanjian dengan Tompo (roh-roh } \\
\text { leluhur) }\end{array}$ & $\begin{array}{l}\text { Pencurahan darah korban merujuk } \\
\text { kepada karya Kristus dalam } \\
\text { penebusan dan penyelamatan orang } \\
\text { berdosa }\end{array}$ \\
\hline
\end{tabular}

\section{Ritus Pencurahan Darah Korban Binatang: Sebuah Point of Contac antara Injil dengan Tradisi Manengeh}

Dalam pengalaman budaya masyarakat adat suku dayak Bumate, didapati sebuah ritus yang relevan dengan berita Injil. Ritus tersebut adalah pencurahan darah korban binatang. Di dalam suku Bumate, pemaknaan ritus tersebut sangat jelas yaitu sebagai jaminan keselamatan jiwa, ucapan syukur dan memperkuat janji dengan para leluhur (Baca: Tompo). Pemaknaan atas ritus tersebut rupanya relevan dengan korban pencurahan darah binatang yang ada di dalam Alkitab. Melalui sintesis teologis, penulis berusaha mendialogkan ritus pencurahan darah dalam tradisi Manegeh dengan tradisi dalam Perjanjian Lama dan Perjanjian Baru untuk memperoleh titik temu yang tepat bagi pengkomunikasian Injil kepada suku dayak Bumate.

Peserta budaya Manengeh memahamai betul bahwa keberhasilan panen bukan saja hasil usaha mereka sendiri, namun ada kekuatan adi kordati yang berperan didalamnya. Keberhasilan ini dirayakan secara besama-sama dengan para leluhur yang telah meninggal, yang juga diyakini keterlibatannya dalam keberhasilan panen. Agar prosesi tersebut dapat 11 | Copyright@ 2021, CARAKA, ISSN 2722-1407 (Cetak), 2722-1393 (Online) 
berjalan dengan aman, maka dilaksanakan ritus pencurahan darah korban binatang yang dipercaya dapat memberikan jaminan keselamatan bagi masyarakat adat Bumate, mengingat darah yang dicurahkan merupakan subtitusi dari nyawa para pemberi korban. Korban binatang yang telah disiapkan sebelumnya, akan disembelih dan darahnya akan dipercikkan di atas peralatan yang digunakan dalam upacara adat. Selain berfungsi sebagai penjamin keselamatan, juga dalam menjadi penetralisir dari anasir-anasir jahat yang dapat menggangu peserta budaya Manengeh. Hal lain yang diyakini dari ritus ini adalah penghormatan atas ikatan perjanjian dengan Tompo (roh-roh leluhur) yang telah memberikan perlindungan kepada mereka.

Pesan dan makna di atas, rupanya memiliki beberapa kesejajaran dengan tradisi pencurahan darah korban di dalam Perjanjian Lama. Korban binatang dalam Perjanjian Lama merupakan subsitusi dari nyawa sang pemberi korban. ${ }^{47}$ Melaluinya orang Israel diperdamaikan dengan Allah dikarenakan telah terjadi pertukaran atau penebusan. ${ }^{48}$ Selain itu, melalui korban pencurahan darah binatang tersebut, umat Allah juga diberi kesempatan untuk mengucap syukur, memuliakan dan menghormati Tuhan atas penebusan yang telah diterimanya. ${ }^{49}$ Makna tersebut rupanya sejajar dengan makna dalam ritus pencurahan darah korban binatang dalam tradisi Manengeh pada suku dayak Bumate.

Bila diamati lebih jauh, rupanya ritus pencurahan darah bintang dalam tradisi Manengeh juga memiliki relevansi dengan tradisi Perjanjian Baru. Didalam tradisi Perjanjian Baru, korban penumpahan darah binatang di Perjanjian Lama dimaknai sebagai lambang karya penebusan Kristus bagi orang berdosa. Kristus telah mati sebagai korban untuk memenuhi tuntutan keadilan Allah yang dinyatakan bagi penyelesaian dosa manusia. ${ }^{50}$ Ibrani 10 menyatakan bahwa Yesus merupakan korban yang sempurna, kontras dengan korban-korban yang dipersembahkan di dalam Perjanjian Lama. ${ }^{51}$ Korban tersebut telah menyempurnakan untuk selama-lamanya mereka yang dikuduskan (Ibrani 10:14). Karya Kristus juga telah menaklukkan kuasa Iblis atas orang-orang berdosa sehingga mereka bukan lagi budak Iblis namun menjadi hamba Allah ${ }^{52}$ dan membawa mereka kepada new covenant (Mark 14:24; Mat. 26:28; Luk. 22:19, Yoh. 1:29; 19:31). ${ }^{53}$

Berdasarkan kesejajaran makna di atas, maka terdapat peluang untuk mendialogkan berita Injil dengan tradisi Manegeh melalui ritus pencurahan darah korban. Korban Yesus di

${ }^{47}$ Ibid., 11.

${ }^{48}$ Zai and Ong, "Memahami Konsep Penebusan Dalam Hukum Taurat Dan Penggenapannya Dalam Diri Yesus Kristus," 7.

${ }^{49}$ Purwanto, “Arti Korban Menurut Kitab Imamat," 12.

${ }^{50}$ Ibid., 5.

${ }^{51}$ Tison and Djadi, "Pengajaran Tentang Ibadah Berdasarkan Surat Ibrani 10:19-25 Dan Implimentasinya Dalam Kehidupan Orang Percaya Pada Masa Kini," 41.

52 Salurante, "Ritual Slaughtering of Livestock in 'Aluk Rambu Solo': How the Way of Torajan Appropriate the Doctrine of Jesus as Sacrifice," 70.

53 Ibid., 69. 
diatas kayu salib yang menebus orang berdosa, dapat dikomunikasikan kepada orang Bumate. Pada dasarnya, semua nyawa orang Bumate telah terwakili di dalam korban Yesus Kristus, sama seperti korban binatang yang mereka persembahkan. Melalui pencurahan darah Yesus, setiap orang Bumate yang percaya kepada-Nya mendapat jaminan atas nyawanya. Hal ini sama seperti konsep yang ada dalam alam berpikir orang Bumate yang memandang bahwa darah binatang yang dikorbankan adalah subtitusi dari nyawanya.

Selanjutnya, orang Bumate perlu mendapatkan klarifikasi bahwa korban pencurahan darah Yesus di atas kayu salib memiliki kuasa yang jauh melampaui darah korban binatang dalam tradisi Manengeh. Ritus tersebut hanya merupakan bayangan saja akan karya yang jauh lebih sempurna, yaitu penebusan Kristus. Dengan percaya kepada karya Kristus maka orang Bumate tidak sekedar mendapat jaminan keselamatan dari roh-roh leluhur, namun lebih dari itu yaitu dari Sang Pencipta kehidupan. Bahkan mereka juga mendapat kebebasan dari anasiranasir jahat dan masuk di dalam perjanjian yang baru yaitu keselamatan yang sejati dari Kristus.

Usulan model teologi kontekstual dalam penelitian ini adalah Teologi Pencurahan Darah Korban Binatang yang merupakan sintesis antara konsep korban keselamatan melalui kematian Yesus Kristus di atas kayu salib dengan ritus tradisi Manengeh di suku Dayak Bumate. Melalui ritus tersebut, suku dayak Bumate akan lebih mudah memahaminya, mengingat telah ada "serpihan-serpihan kebenaran" yang dapat disusun ulang dan dikomunikasikan secara kontekstual kepada mereka. Dengan kontekstualisasi ini diharapkan berita Injil akan lebih relevan dengan kebudayaan suku Bumate sehingga berita Injil tidak menjadi asing bagi mereka.

\section{KESIMPULAN}

Berita Injil rupanya memiliki relevasi dengan tradisi Manengeh pada suku dayak Bumate. Penelitian ini menemukan bahwa terdapat point of contac antara ritus pencurahan darah dalam tradisi Manengeh dengan berita Injil yang ada di dalam Alkitab. Melalui ritus tersebut, suku dayak Bumate diperkenalkan dengan kuasa korban Yesus Kristus di atas kayu salib yang menebus mereka. Korban Yesus telah mengganti orang Bumate dari penghukuman Allah akibat dosa, bahkan memberikan jaminan keselamatan jauh melampaui korban binatang yang dicurahkan darahnya tersebut. Selain itu, korban Yesus Kristus telah membebaskan orang Bumate dari anasir-anasir jahat yang mengganggu dan memperbudak mereka. Rupanya di dalam ritus itu terdapat "serpihan-serpihan kebenaran" yang dapat disusun ulang untuk membawa orang Bumate kepada Yesus Kristus. 


\section{REKOMENDASI}

Penelitian ini masih mememiliki banyak kekurangan dan keterbatasan, antara lain keterbatasan literatur tentang suku dayak Bumate, hal ini dikarenakan masih sedikitnya penelitian tentang suku tersebut. Peneliti merekomendasikan agar lebih banyak lagi penelitian yang dilakukan terhadap suku ini. Selanjutnya peneliti menemukan adanya unsur-unsur dalam tradisi Manengeh yang harus lebih dieksplorasi, semisal keterlibatan Tokoh Spiritual dalam upacara adat, penentuan waktu yang tepat serta jenis-jenis korban binatang yang dipersembahkan beserta maknanya yang pastinya akan menambah pengetahuan tentang world view suku dayak Bumate bagi pengkomunikasian Injil yang lebih mendalam.

\section{DAFTAR PUSTAKA}

Aliyanto, Deky Nofa, and Sinta Kumala Sari. "Makna Warna Merah Dalam Tradisi Etnis Tionghoa Sebagai Jembatan Komunikasi Untuk Memperkenalkan Makna Darah Yesus." Jurnal Gamaliel : Teologi Praktika 1, no. 2 (2019): 203.

_. "Makna Warna Merah Dalam Tradisi Etnis Tionghoa Sebagai Jembatan Komunikasi Untuk Memperkenalkan Makna Darah Yesus" 1, no. 2 (2019): 93-103.

Banawiratma, J.B. "Teologi Fungsional-Teologi Kontekstual." In Konteks Berteologi Di Indonesia, edited by Eka Darmaputera. Jakarta: Gunung Mulia, 2004.

Gea, Ibelala. "Beritakan Injil Kepada Segala Makhluk." BIA': Jurnal Teologi dan Pendidikan Kristen Kontekstual 1, no. 1 (2018): 56-69.

Harming, Harming. "Metode Penginjilan Yesus Dalam Injil Yohanes 4:1-42." Evangelikal: Jurnal Teologi Injili dan Pembinaan Warga Jemaat 1, no. 2 (2017): 162.

Hendrikus Primus Siu. "Nilai Dan Simbol Religius Perjamuan Raya ( Nado Mere ) Masyarakat Jawawawo: Studi Komparatif Inkulturatif Dengan Nilai-Nilai Ekaristi." Jurnal Masalah Pastoral 3, no. 1 (2014): 15-36.

Hutagalung, Patrecia. "Pemuridan Sebagai Mandat Misi Menurut Matius 28:18-20." Pengarah: Jurnal Teologi Kristen 2, no. 1 (2020): 64-76.

Kartono, Kartini. Pengantar Metodologi Research Sosial. Bandung: Alumni Bandung, 1980.

Morrisan, M. A. Metode Penelitian Survei. Jakarta, 2012.

Park, Yune Sun. Tafsiran Kitab Kejadian. Batu: Dept. Literatur YPPII, 2002.

Purwanto, Ani Teguh. “Arti Korban Menurut Kitab Imamat.” Journal Kerusso 2, no. 2 (2017): $8-14$.

Rayo, Kandida Maro. "Eksplorasi Kosakata Matematis Dalam Budaya Tak Kasat Mata Suku Dayak Bidayuh-Somu Di Desa Sebuduh Kecamatan Kembayan." Jurnal Pendidikan dan Pembelajaran Khatulistiwa 7, no. 8 (2018).

Rowley, H.H. Ibadah Israel Kuno. Jakarta: BPK Gunung Mulia, 1981.

Salurante, Tony. "Ritual Slaughtering of Livestock in 'Aluk Rambu Solo': How the Way of Torajan Appropriate the Doctrine of Jesus as Sacrifice.” Diegesis Vol.5 No.2 (2020): 6477.

Setiawan, David Eko. "Menjembatani Injil Dan Budaya Dalam Misi Melalui Metode Kontektualisasi." Fidei: Jurnal Teologi Sistematika dan Praktika 3, no. 2 (2020): 160180.

Suyanto, Bagong. Metode Penelitian Sosial: Berbagai Alternatif Pendekatan. Jakarta, 2015.

Tison, and Jermia Djadi. "Pengajaran Tentang Ibadah Berdasarkan Surat Ibrani 10:19-25 Dan Implimentasinya Dalam Kehidupan Orang Percaya Pada Masa Kini.” Jurna Jaffray 11, no. 1 (2013).

Warjianto, Ayub, and Fibry Jati Nugroho. "Teologi Penghormatam: Dialog Kekristenan 
Dengan Ritus Kembang Kuningan.” Visio Dei: Jurnal Teologi Kristen 2, no. 1 (2020): 147-167.

Wiwin, Tea Tasia. "Matematika Dalam Budaya Memperingati Anak Bulan Di Masayarakat Suku Dayak Dusun Terusan Kalimantan Barat." In Matematika Dalam Budaya: Kumpulan Kajian Etnomatematika, edited by M. Andy Rudhito, FX. Catur Supatmono, and Gabriela Purnama Ningsi. Yogyakarta: Garudhawaca, 2019.

Zai, Iman Nuel, and Thuan Ong. "Memahami Konsep Penebusan Dalam Hukum Taurat Dan Penggenapannya Dalam Diri Yesus Kristus." Jurnal Teologi Pondok Daud 6, no. 1 (2020). 